\title{
АНАЛІЗ СТАНУ ГОТЕЛЬНОГО ГОСПОДАРСТВА РЕГІОНІВ УКРАЇНИ
}

\author{
Рябсв А.А., канд. екон. наук, доцент
}

Харківський національний університет міського господарства ім. О.М. Бекетова

Постановка проблеми. Існуючі в Україні форми та методи регулювання діяльності готельного господарства не повною мірою враховують кон'юнктуру ринку, спрямованість спеціалізації регіонів на відповідну орієнтацією бізнесу, повне використання наявних природних, історико-культурних та інших ресурсів. Тому виникає вельми актуальна необхідність проведення теоретичних досліджень щодо вдосконалення механізмів регулювання попиту та пропозиції туристичної діяльності, в тому числі готельного господарства, покращення дії окремих елементів цієї системи, формування сучасної системи інформаційноаналітичного забезпечення, системи моніторингу ринку готельних послуг.

Аналіз останніх досліджень i публікацій. Проблеми, пов'язані 3 оцінюванням стану готельного господарства України та “iі регіонів, досліджували вітчизняні вчені М.П. Мальська, М.Й. Рутинський, Н.М. Паньків, М.К. Бойко, С.В. Мельниченко, А.А. Мазаракі, Т.І. Ткаченко та ін.

Виділення невирішених раніше частин загальної проблеми. Більшість досліджень готельного господарства як складової туристичної галузі зосереджено на тому, що необхідно стимулювати розвиток туризму різноманітними засобами, одним з яких є збільшення кількості місць і номерів в готелях та аналогічних засобах розміщення. Проте, на практиці відбувається переважно створення готелів середньої та верхньої цінових категорій, які для більшості потенційних подорожуючих знаходяться за межами уваги.

Формулювання цілей статті. Виходячи 3 невирішеності проблемного питання, необхідно визначити стан і динаміку розвитку готельного господарства регіонів України як складової туристичної галузі, що дозволить виділити напрями перспективного розвитку готельного господарства в регіонах України.

Виклад основного матеріалу дослідження. Складовою готельного бізнесу є економічна діяльність спеціалізованих підприємств, які пропонують на підприємницькій основі послуги та забезпечують споживачів, котрі подорожують, необхідними умовами для розміщення та харчування.

За визначенням [1] готельне господарство - це сукупність готельних підприємств різних типів, що приймають і надають послуги 3 розміщення, харчування, додаткові та суміжні послуги.

Термін «готельне господарство» використовується не тільки для визначення діяльності готелів, а й інших типів засобів розміщення - мотелі, хостели, кемпінги, туристські бази й інші. Наразі готелі належать до домінуючого типу засобів розміщення, що визначив назву сфери діяльності. 
Специфікою економічної сутності готельної сфери діяльності є надання послуг нематеріального характеру. Особливість надання послуг гостинності пов'язана 3 тим, що вони створюються та реалізуються в межах одного підприємства. Якість і асортимент послуг готельного бізнесу зумовлені наявністю та станом матеріально-технічної бази, а також кваліфікацією персоналу закладу розміщення.

Загальну динаміку кількості надавачів готельних послуг в Україні за 2011-2016 рр. відображено на рис. 1.

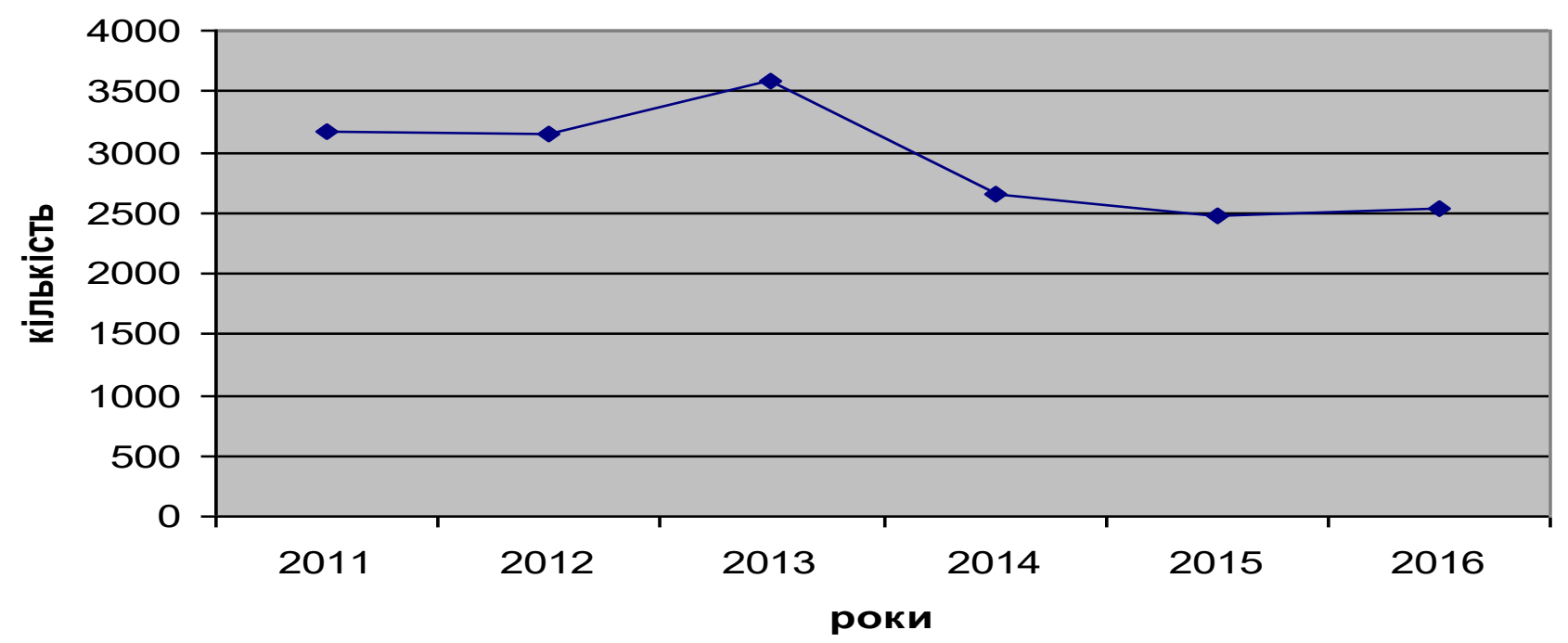

Рис. 1. Динаміка кількості готелів та аналогічних засобів розміщування громадян в Україні за 2011-2016 pp.

Можна зазначити, що за період 2011-2013 pp. розвиток послуг гостинності мав позитивний характер. Важке криміногенне положення на Донбасі та в АР Крим позначилось негативними наслідками на галузі протягом 2014-2016 pр. 32016 року почалося пожвавлення ринку готельних послуг України.

Стан і динаміку розвитку надавачів готельних послуг по регіонах України можна дослідити в табл. 1-3.

Таблиия 1

\section{Кількість готелів та аналогічних засобів розміщування громадян} по регіонах України за 2011-2016 рр., од. [2]

\begin{tabular}{|l|c|c|c|c|c|c|}
\hline \multirow{2}{*}{\multicolumn{1}{|c|}{ Регіони }} & \multicolumn{7}{c|}{ Роки } \\
\cline { 2 - 7 } \multicolumn{1}{|c|}{1} & 2011 & 2012 & 2013 & 2014 & 2015 & 2016 \\
\hline Вінницька область & 2 & 3 & 4 & 5 & 6 & 7 \\
\hline Волинська область & 46 & 61 & 72 & 73 & 75 & 60 \\
\hline Дніпропетровська область & 46 & 50 & 67 & 64 & 66 & 61 \\
\hline Донецька область & 141 & 130 & 135 & 146 & 139 & 138 \\
\hline Житомирська область & 140 & 135 & 139 & 50 & 44 & 46 \\
\hline Закарпатська область & 48 & 51 & 57 & 59 & 58 & 70 \\
\hline Запорізька область & 159 & 151 & 228 & 229 & 213 & 211 \\
\hline Івано-Франківська область & 116 & 89 & 126 & 125 & 86 & 114 \\
\hline
\end{tabular}


Продовження табличі 1

\begin{tabular}{|l|c|c|c|c|c|c|}
\hline \multicolumn{1}{|c|}{1} & 2 & 3 & 4 & 5 & 6 & 7 \\
\hline Київська область & 56 & 57 & 93 & 89 & 87 & 114 \\
\hline Кіровоградська область & 32 & 43 & 45 & 48 & 41 & 30 \\
\hline Луганська область & 60 & 45 & 51 & 13 & 23 & 23 \\
\hline Львівська область & 228 & 250 & 272 & 273 & 273 & 287 \\
\hline Миколаївська область & 70 & 82 & 93 & 89 & 66 & 74 \\
\hline Одеська область & 217 & 216 & 253 & 235 & 250 & 232 \\
\hline Полтавська область & 86 & 94 & 115 & 106 & 105 & 76 \\
\hline Рівненська область & 41 & 44 & 52 & 50 & 46 & 45 \\
\hline Сумська область & 48 & 47 & 50 & 41 & 34 & 37 \\
\hline Тернопільська область & 46 & 49 & 59 & 58 & 57 & 59 \\
\hline Харківська область & 103 & 125 & 130 & 125 & 123 & 108 \\
\hline Херсонська область & 74 & 82 & 116 & 109 & 70 & 92 \\
\hline Хмельницька область & 60 & 68 & 90 & 84 & 70 & 71 \\
\hline Черкаська область & 70 & 66 & 75 & 73 & 75 & 80 \\
\hline Чернівецька область & 67 & 80 & 87 & 91 & 87 & 79 \\
\hline Чернігівська область & 44 & 45 & 45 & 45 & 43 & 35 \\
\hline м. Київ & 156 & 148 & 145 & 157 & 147 & 165 \\
\hline
\end{tabular}

Таблиия 2

Ранжування регіонів України за кількістю готелів та аналогічних засобів розмішування громадян за 2011-2016 pp. [4]

\begin{tabular}{|l|c|c|c|c|c|c|}
\hline \multirow{2}{*}{ Регіони } & \multicolumn{7}{|c|}{ Місце за рейтингом } \\
\cline { 2 - 7 } & 2011 p. & 2012 p. & 2013 p. & 2014 p. & 2015 p. & $2016 \mathrm{p}$. \\
\hline Львівська область & 2 & 1 & 1 & 1 & 1 & 1 \\
\hline Одеська область & 3 & 2 & 2 & 2 & 2 & 2 \\
\hline Івано-Франківська область & 1 & 3 & 4 & 4 & 4 & 3 \\
\hline Закарпатська область & 4 & 4 & 3 & 3 & 3 & 4 \\
\hline м. Київ & 5 & 5 & 5 & 5 & 5 & 5 \\
\hline Дніпропетровська область & 6 & 7 & 7 & 6 & 6 & 6 \\
\hline Запорізька область & 7 & 10 & 9 & 7 & 11 & 7 \\
\hline Київська область & 17 & 17 & 12 & 12 & 9 & 8 \\
\hline Харківська область & 8 & 8 & 8 & 8 & 7 & 9 \\
\hline Херсонська область & 11 & 11 & 10 & 9 & 14 & 10 \\
\hline Черкаська область & 12 & 15 & 16 & 15 & 12 & 11 \\
\hline Чернівецька область & 14 & 13 & 15 & 11 & 10 & 12 \\
\hline Полтавська область & 9 & 9 & 11 & 10 & 8 & 13 \\
\hline Миколаївська область & 13 & 12 & 13 & 13 & 16 & 14 \\
\hline Хмельницька область & 15 & 14 & 14 & 14 & 15 & 15 \\
\hline Житомирська область & 18 & 17 & 20 & 18 & 18 & 16 \\
\hline Волинська область & 20 & 18 & 18 & 17 & 17 & 17 \\
\hline Вінницька область & 21 & 16 & 17 & 16 & 13 & 18 \\
\hline Тернопільська область & 22 & 19 & 19 & 19 & 19 & 19 \\
\hline Донецька область & 7 & 6 & 6 & 20 & 21 & 20 \\
\hline Рівненська область & 24 & 24 & 21 & 21 & 20 & 21 \\
\hline Сумська область & 19 & 20 & 23 & 24 & 24 & 22 \\
\hline Чернігівська область & 23 & 21 & 24 & 23 & 22 & 23 \\
\hline Кіровоградська область & 25 & 25 & 25 & 22 & 23 & 24 \\
\hline Луганська область & 16 & 22 & 22 & 25 & 25 & 25 \\
\hline
\end{tabular}


Можна визначити групу регіонів-лідерів за кількістю готелів: Львівський, Одеський, Івано-Франківський, Закарпатський, Дніпропетровський регіони та м. Київ. Визначені регіони за досліджений період постійно знаходилися в групі лідерів.

У середній групі рейтингу відбувалися різноспрямовані коливання.

У групі аутсайдерів знаходяться Тернопільський, Донецький, Рівненський, Сумський, Чернігівський, Кіровоградський і Луганський регіони.

Таблиця 3

\section{Динаміка зміни кількості готелів та аналогічних засобів розміщування громадян по регіонах України за 2012-2016 рр. [2]}

\begin{tabular}{|l|c|c|c|c|c|}
\hline \multirow{2}{*}{ Регіони } & \multicolumn{5}{c|}{ \% до попереднього року } \\
\cline { 2 - 6 } & $2012 \mathrm{p}$. & $2013 \mathrm{p}$. & $2014 \mathrm{p}$. & $2015 \mathrm{p}$. & $2016 \mathrm{p.}$ \\
\hline Вінницька область & 133 & 118 & 101 & 103 & 80 \\
\hline Волинська область & 109 & 134 & 96 & 103 & 92 \\
\hline Дніпропетровська область & 92 & 104 & 108 & 95 & 99 \\
\hline Донецька область & 96 & 103 & 36 & 88 & 105 \\
\hline Житомирська область & 106 & 112 & 104 & 98 & 121 \\
\hline Закарпатська область & 95 & 151 & 100 & 93 & 99 \\
\hline Запорізька область & 77 & 142 & 99 & 69 & 133 \\
\hline Івано-Франківська область & 48 & 116 & 110 & 94 & 114 \\
\hline Київська область & 102 & 163 & 96 & 98 & 131 \\
\hline Кіровоградська область & 134 & 105 & 107 & 85 & 73 \\
\hline Луганська область & 75 & 113 & 25 & 177 & 100 \\
\hline Львівська область & 110 & 109 & 100 & 100 & 105 \\
\hline Миколаївська область & 117 & 113 & 96 & 74 & 112 \\
\hline Одеська область & 100 & 117 & 93 & 106 & 93 \\
\hline Полтавська область & 109 & 122 & 92 & 99 & 72 \\
\hline Рівненська область & 107 & 118 & 96 & 92 & 98 \\
\hline Сумська область & 98 & 106 & 82 & 83 & 109 \\
\hline Тернопільська область & 107 & 120 & 98 & 98 & 104 \\
\hline Харківська область & 121 & 104 & 96 & 98 & 88 \\
\hline Херсонська область & 111 & 141 & 94 & 64 & 131 \\
\hline Хмельницька область & 113 & 132 & 93 & 83 & 101 \\
\hline Черкаська область & 94 & 114 & 97 & 103 & 107 \\
\hline Чернівецька область & 119 & 109 & 105 & 96 & 91 \\
\hline Чернігівська область & 102 & 100 & 100 & 96 & 81 \\
\hline м. Київ & 95 & 98 & 108 & 94 & 112 \\
\hline
\end{tabular}

Можна зазначити, що динаміка зміни кількості готелів та аналогічних засобів розміщування громадян по регіонах України мала хвилеподібний характер. Найбільші скорочення кількості готелів та аналогічних засобів розмішування громадян відбувалися в 2015 році у Запорізькому, Миколаївському, Херсонському, Кіровоградському регіонах. Найбільше відкрилося готелів у 2013 році у Волинському, Закарпатському, Запорізькому, Київському, Херсонському, Хмельницькому регіонах. Така характеристика не враховує показники 20132017 pp. Донецького та Луганського регіонів.

Стан і динаміку кількості місць у колективних засобах розміщування громадян по регіонах України можна дослідити за допомогою табл. 4-5. 
Таблиия 4

Динаміка кількості місць у колективних засобах розміщування громадян по регіонах України за 2012-2016 рр. [2]

\begin{tabular}{|l|c|c|c|c|c|}
\hline \multirow{2}{*}{ Регіони } & \multicolumn{5}{c|}{ \% до попереднього року } \\
\cline { 2 - 6 } & $2012 \mathrm{p}$. & $2013 \mathrm{p}$. & $2014 \mathrm{p}$. & $2015 \mathrm{p}$. & $2016 \mathrm{p.}$ \\
\hline Вінницька область & 115 & 105 & 96 & 108 & 92 \\
\hline Волинська область & 107 & 123 & 98 & 102 & 112 \\
\hline Дніпропетровська область & 97 & 103 & 101 & 97 & 96 \\
\hline Донецька область & 119 & 100 & 47 & 75 & 103 \\
\hline Житомирська область & 94 & 105 & 98 & 108 & 118 \\
\hline Закарпатська область & 88 & 158 & 105 & 93 & 113 \\
\hline Запорізька область & 100 & 101 & 112 & 87 & 109 \\
\hline Івано-Франківська область & 86 & 108 & 109 & 98 & 126 \\
\hline Київська область & 101 & 150 & 99 & 104 & 106 \\
\hline Кіровоградська область & 113 & 124 & 104 & 76 & 111 \\
\hline Луганська область & 61 & 119 & 28 & 172 & 104 \\
\hline Львівська область & 122 & 105 & 104 & 106 & 101 \\
\hline Миколаївська область & 94 & 125 & 94 & 95 & 102 \\
\hline Одеська область & 113 & 101 & 109 & 105 & 98 \\
\hline Полтавська область & 115 & 105 & 94 & 101 & 96 \\
\hline Рівненська область & 84 & 111 & 90 & 102 & 109 \\
\hline Сумська область & 114 & 91 & 99 & 84 & 110 \\
\hline Тернопільська область & 109 & 109 & 94 & 111 & 112 \\
\hline Харківська область & 118 & 106 & 96 & 97 & 97 \\
\hline Херсонська область & 102 & 125 & 96 & 77 & 106 \\
\hline Хмельницька область & 106 & 110 & 98 & 101 & 102 \\
\hline Черкаська область & 107 & 107 & 92 & 102 & 106 \\
\hline Чернівецька область & 104 & 108 & 104 & 100 & 103 \\
\hline Чернігівська область & 108 & 93 & 97 & 98 & 110 \\
\hline м. Київ & 95 & 110 & 112 & 95 & 89 \\
\hline & & & & & \\
\hline
\end{tabular}

Найгірший результат (скорочення кількості місць у колективних засобах розміщування громадян) у 2015 році мав Кіровоградський регіон, слідом за ним йшли Херсонський, Сумський і Запорізький регіони.

За кількістю нових місць у колективних засобах розміщування громадян у 2013 році, відповідно до табл. 4, лідером був Тернопільський регіон, слідом за ним Вінницький, Житомирський, Львівський та Одеський регіони, не враховуючи показники 2013-2017 pp. Донецького та Луганського регіонів. Зазначимо, що Донецький регіон мав другий найкращий результат за цим показником у 2012 році (після Львівського регіону).

Таблиия 5

Ранжування регіонів України за кількістю місць у колективних засобах розміщування громадян за 2012-2016 рр. [4]

\begin{tabular}{|l|c|c|c|c|c|}
\hline \multirow{2}{*}{ Регіони } & \multicolumn{5}{|c|}{ Місце за рейтингом } \\
\cline { 2 - 6 } & $2012 \mathrm{p}$. & $2013 \mathrm{p}$. & $2014 \mathrm{p}$. & $2015 \mathrm{p}$. & $2016 \mathrm{p}$. \\
\hline \multicolumn{1}{|c|}{1} & 2 & 3 & 4 & 5 & 6 \\
\hline м. Київ & 1 & 1 & 1 & 1 & 1 \\
\hline Львівська область & 2 & 2 & 2 & 2 & 2 \\
\hline Одеська область & 3 & 3 & 3 & 3 & 3 \\
\hline
\end{tabular}


Продовження таблииі 5

\begin{tabular}{|l|c|c|c|c|c|}
\hline \multicolumn{1}{|c|}{1} & 2 & 3 & 4 & 5 & 6 \\
\hline Івано-Франківська область & 6 & 6 & 5 & 5 & 4 \\
\hline Закарпатська область & 7 & 4 & 4 & 4 & 5 \\
\hline Дніпропетровська область & 4 & 5 & 6 & 6 & 6 \\
\hline Запорізька область & 8 & 8 & 7 & 7 & 7 \\
\hline Харківська область & 9 & 9 & 8 & 8 & 8 \\
\hline Київська область & 13 & 10 & 9 & 9 & 9 \\
\hline Полтавська область & 10 & 11 & 10 & 10 & 10 \\
\hline Чернівецька область & 11 & 14 & 12 & 11 & 11 \\
\hline Хмельницька область & 13 & 13 & 13 & 12 & 12 \\
\hline Херсонська область & 12 & 12 & 11 & 13 & 13 \\
\hline Тернопільська область & 16 & 17 & 17 & 14 & 14 \\
\hline Черкаська область & 14 & 16 & 16 & 16 & 15 \\
\hline Миколаївська область & 15 & 15 & 15 & 15 & 16 \\
\hline Донецька область & 5 & 7 & 14 & 17 & 17 \\
\hline Житомирська область & 18 & 21 & 19 & 19 & 18 \\
\hline Волинська область & 21 & 19 & 20 & 20 & 19 \\
\hline Вінницька область & 17 & 18 & 18 & 18 & 20 \\
\hline Чернігівська область & 19 & 24 & 21 & 21 & 21 \\
\hline Рівненська область & 22 & 22 & 22 & 22 & 22 \\
\hline Кіровоградська область & 25 & 23 & 23 & 23 & 23 \\
\hline Сумська область & 24 & 25 & 24 & 24 & 24 \\
\hline Луганська область & 20 & 20 & 25 & 25 & 25 \\
\hline
\end{tabular}

За результатами рейтингу можна визначити незмінну в означеному періоді групу регіонів-лідерів за кількістю місць у колективних засобах розміщування: м. Київ, Львівський, Одеський, Івано-Франківський, Закарпатський регіони. Відзначимо, що за досліджений період ІваноФранківський регіон набув найбільшого прогресу в групі лідерів, піднявшись на дві позиції в рейтингу.

У середній групі відбувалися мінімальні коливання, окрім Донецького регіону, який втратив 12 позицій.

У групі аутсайдерів знаходяться Чернігівський, Рівненський, Кіровоградський, Сумський і Луганський регіони. Регіони-аутсайдери мають стабільні позиції, окрім Луганського регіону, який втратив 5 позицій та опинився на останньому місці. До 2014 року Донецький регіон стабільно знаходився за цим показником у групі лідерів.

Рейтинг і динаміку регіонів України за показником кількості місць у колективних засобах розміщування громадян можна дослідити за табл. 6-7.

Таблиия 6

Динаміка зміни кількості розміщених осіб у колективних засобах розміщування громадян по регіонах України за 2012-2016 рр. [2]

\begin{tabular}{|c|c|c|c|c|c|}
\hline \multirow{2}{*}{ Регіони } & \multicolumn{5}{|c|}{ \% до попереднього року } \\
\cline { 2 - 6 } & $2012 \mathrm{p}$. & $2013 \mathrm{p}$. & $2014 \mathrm{p}$. & $2015 \mathrm{p}$. & $2016 \mathrm{p}$. \\
\hline 1 & 2 & 3 & 4 & 5 & 6 \\
\hline Вінницька область & 153 & 87 & 107 & 99 & 111 \\
\hline Волинська область & 83 & 121 & 89 & 110 & 106 \\
\hline
\end{tabular}


Продовження таблиці 6

\begin{tabular}{|l|c|c|c|c|c|}
\hline \multicolumn{1}{|c|}{1} & 2 & 3 & 4 & 5 & 6 \\
\hline Дніпропетровська область & 112 & 163 & 58 & 103 & 113 \\
\hline Донецька область & 125 & 98 & 35 & 110 & 53 \\
\hline Житомирська область & 122 & 108 & 86 & 109 & 120 \\
\hline Закарпатська область & 107 & 123 & 83 & 117 & 123 \\
\hline Запорізька область & 102 & 110 & 102 & 87 & 112 \\
\hline Івано-Франківська область & 130 & 94 & 105 & 109 & 122 \\
\hline Київська область & 108 & 110 & 96 & 92 & 155 \\
\hline Кіровоградська область & 105 & 124 & 95 & 106 & 107 \\
\hline Луганська область & 95 & 112 & 5 & 419 & 105 \\
\hline Львівська область & 119 & 105 & 91 & 132 & 127 \\
\hline Миколаївська область & 97 & 84 & 95 & 108 & 121 \\
\hline Одеська область & 100 & 120 & 61 & 133 & 116 \\
\hline Полтавська область & 115 & 117 & 88 & 128 & 100 \\
\hline Рівненська область & 112 & 131 & 86 & 97 & 97 \\
\hline Сумська область & 88 & 103 & 103 & 77 & 126 \\
\hline Тернопільська область & 155 & 110 & 84 & 116 & 155 \\
\hline Харківська область & 99 & 108 & 80 & 106 & 106 \\
\hline Херсонська область & 155 & 92 & 95 & 79 & 204 \\
\hline Хмельницька область & 112 & 101 & 83 & 102 & 112 \\
\hline Черкаська область & 107 & 111 & 103 & 112 & 116 \\
\hline Чернівецька область & 114 & 117 & 88 & 99 & 102 \\
\hline Чернігівська область & 113 & 99 & 83 & 92 & 119 \\
\hline м. Київ & 88 & 107 & 76 & 119 & 114 \\
\hline
\end{tabular}

Динаміка зміни кількості розміщених осіб у колективних засобах розміщування громадян по регіонах України мала хвилеподібний характер. Найбільші скорочення кількості розміщених осіб у колективних засобах розміщування громадян за досліджений період відбувалися у 2014 році у Дніпропетровському, Закарпатському, Одеському, Харківському, Чернігівському регіонах та м. Київ.

Найвища динаміка збільшення кількості розміщених осіб у колективних засобах розміщування громадян була у 2016 році у Житомирському, Закарпатському, Івано-Франківському, Київському, Львівському, Тернопільському та Херсонському регіонах, не враховуючи показники 20132016 pp. Донецького та Луганського регіонів. Можна відзначити, що у 2012 році Донецький регіон мав один із найвищих показників збільшення кількості розміщених осіб у колективних засобах розміщування громадян.

Таблиия 7

\section{Рейтинг регіонів України за кількістю розміщених осіб у колективних} засобах розміщування громадян за 2012-2016 рр. [2]

\begin{tabular}{|l|c|c|c|c|c|}
\hline \multirow{2}{*}{ Регіони } & \multicolumn{5}{c|}{ Місце за рейтингом } \\
\cline { 2 - 6 } & $2012 \mathrm{p}$. & $2013 \mathrm{p}$. & $2014 \mathrm{p}$. & $2015 \mathrm{p}$. & $2016 \mathrm{p}$. \\
\hline \multicolumn{1}{|c|}{1} & 2 & 3 & 4 & 5 & 6 \\
\hline м. Київ & 1 & 1 & 1 & 1 & 1 \\
\hline Львівська область & 2 & 2 & 2 & 2 & 2 \\
\hline Івано-Франківська область & 6 & 7 & 3 & 3 & 3 \\
\hline
\end{tabular}


Продовження таблиці 7

\begin{tabular}{|l|c|c|c|c|c|}
\hline \multicolumn{1}{|c|}{1} & 2 & 3 & 4 & 5 & 6 \\
\hline Одеська область & 4 & 4 & 6 & 4 & 4 \\
\hline Київська область & 8 & 8 & 7 & 9 & 5 \\
\hline Дніпропетровська область & 7 & 3 & 4 & 6 & 6 \\
\hline Харківська область & 3 & 5 & 5 & 5 & 7 \\
\hline Закарпатська область & 10 & 9 & 9 & 8 & 8 \\
\hline Тернопільська область & 12 & 12 & 11 & 11 & 9 \\
\hline Полтавська область & 11 & 11 & 10 & 7 & 10 \\
\hline Хмельницька область & 9 & 10 & 8 & 10 & 11 \\
\hline Черкаська область & 18 & 17 & 15 & 12 & 12 \\
\hline Чернівецька область & 13 & 14 & 14 & 14 & 13 \\
\hline Рівненська область & 14 & 13 & 12 & 13 & 14 \\
\hline Запорізька область & 15 & 15 & 13 & 15 & 15 \\
\hline Миколаївська область & 17 & 20 & 19 & 19 & 16 \\
\hline Волинська область & 20 & 18 & 18 & 17 & 17 \\
\hline Вінницька область & 19 & 19 & 17 & 18 & 18 \\
\hline Херсонська область & 23 & 25 & 24 & 24 & 19 \\
\hline Житомирська область & 22 & 22 & 22 & 20 & 20 \\
\hline Чернігівська область & 21 & 21 & 20 & 21 & 21 \\
\hline Кіровоградська область & 25 & 24 & 23 & 22 & 22 \\
\hline Сумська область & 24 & 23 & 21 & 23 & 23 \\
\hline Донецька область & 5 & 6 & 16 & 16 & 24 \\
\hline Луганська область & 16 & 16 & 25 & 25 & 25 \\
\hline
\end{tabular}

За результатами рейтингу можна визначити незмінну за означений період групу регіонів-лідерів за кількістю розміщених осіб у колективних засобах розміщування громадян: м. Київ та Львівський регіон. У групі лідерів 2016 р. опинилися Івано-Франківський, Одеський, Київський, Дніпропетровський регіони. Серед них Івано-Франківський регіон і Київський регіон набули найбільшого прогресу в групі лідерів, піднявшись на три позиції в рейтингу.

У середній групі відбувалися незначні різноспрямовані коливання.

У групі аутсайдерів знаходяться Чернігівський, Кіровоградський, Сумський, Донецький i Луганський регіони. Регіони-аутсайдери мають стабільні позиції, окрім Донецького регіону та Луганського регіону, які втратили 19 і 6 позицій, відповідно. Луганський регіон опинився на останньому місці рейтингу за кількістю розміщених осіб у колективних засобах розміщування громадян.

Проведений аналіз дозволяє визначити регіони-лідери за наданням послуг гостинності: м. Київ, Львівський, Івано-Франківський і Одеський регіони. Серед аутсайдерів - Чернігівський, Рівненський, Кіровоградський і Сумський регіони.

Донецький регіон i Луганський регіон мають значний туристичний потенціал, але наразі опинилися в групі аутсайдерів.

Глобалізація світової економічної системи, жорстке конкурентне середовище та технічний прогрес сприяють постійному пошуку нових послуг, 
розширенню й урізноманітненню матеріально-технічної бази та змінам структури персоналу готелів.

Наявне конкурентне середовище сприяє все більше урізноманітнювати, ускладнювати послуги гостинності, вони набувають комплексного характеру. Сучасна готельна індустрія неможлива без утворення поряд 3 основними будівлями готелів розважальних і спортивних закладів, споруд для шопінгу та інших.

Наявні конкурентні умови сприяють пошуку нових потенційних продуктів, які мають охоплювати ймовірні напрями діяльності, що приведуть до переваг надавачів готельних послуг у ринковому позиціюванні, зможуть утримати та залучити нових клієнтів.

Представниками готельного бізнесу широко використовується термін «готельний продукт», що наголошує на комплексному характері готельних послуг.

Загалом, категорія «готельний продукт» відображає результат господарської діяльності, поданий у матеріальній формі (матеріальний продукт), духовній, інформаційній (інтелектуальний продукт) або у формі виконання робіт і послуг [3].

Вагомою характеристикою послуг гостинності $\epsilon$ неоднорідність якості обслуговування споживачів. Така характеристика відрізняє їх від промислової діяльності. Споживачі готельних послуг $є$ важливим елементом мінливості якості надання послуг. Відмінності й особистості потреб клієнтів зумовлюють високу ступінь індивідуалізації послуг і унеможливлюють масовий характер їх надання. Для надання більшої масовості та зниження неоднорідності якості послуг у більшості готельних підприємств розроблені та підтримуються стандарти обслуговування. Стандарти послуг гостинності містять комплекс обов'язкових норм i правил для обслуговування клієнтів, забезпечують встановлений рівень якості всіх наданих послуг і відповідних проміжних операцій. Необхідно зазначити, що визначення еталонів і вимірювання якості послуг гостинності створює необхідність реалізації комплексного підходу, $\epsilon$ складним та у значній мірі суб'єктивним процесом.

Підвищення категорії суб'єкту індустрії гостинності вимагає відповідного обладнання, необхідних приміщень служби сервісу, оснащення його товарною продукцією. Означені сервіс-служби спрямовані на обрану спеціалізацію: побутові послуги - service-room, послуги ділового характеру бізнес-центр (факс, ксерокс, комп'ютери з виходом в Інтернет та електронною поштою, послуги перекладача, стенографістки, прокат автотранспорту), доставка їжі в номер - room-service, рекреаційні послуги - СПА-центр, тренажерні зали. Організація відповідного готельного сервісу потребує технічної культури, яка забезпечується якістю матеріальної бази готелів. Це не тільки якість будинку, а й відповідність архітектурно-будівельним стандартам, організація внутрішніх приміщень, їх функціональних зв'язків, якість інженерного та санітарного обладнання, наявність засобів автоматизації та 
механізації обслуговування. Забезпечення високої якості технічної та управлінської культури неможливе без використання автоматизованих систем управління і автоматизації робочих місць персоналу, комп'ютерної техніки та відповідних програм. Саме такі заходи створюють в умовах конкуренції можливості поширювати свої послуги, просувати їх на ринку туристичних послуг та знаходити нові групи споживачів. Подібні заходи потребують значних фінансових ресурсів і, відповідно, інвестицій.

Динаміку обсягів інвестицій в основний капітал діяльності готелів та ресторанів України за 2010-2016 рр. відображено в табл. 8 та на рис. 2.

Таблиия 8

Обсяги інвестицій в основний капітал діяльності готелів та ресторанів

в Україні в 2010-2016 рр., тис. грн. [2]

\begin{tabular}{|c|c|c|c|c|c|c|c|}
\hline Назва & 2010 p. & 2011 p. & 2012 p. & 2013 p. & 2014 p. & 2015 p. & $2016 \mathrm{p}$. \\
\hline Діяльність готелів & 1232364 & 1510621 & 1423175 & 774322 & 1139646 & 1014478 & 1107200 \\
\hline $\begin{array}{c}\text { Надання інших місць } \\
\text { для тимчасового } \\
\text { проживання }\end{array}$ & 968426 & 1068801 & 788557 & 371720 & 509495 & 332364 & 406906 \\
\hline $\begin{array}{c}\text { Діяльність } \\
\text { ресторанів }\end{array}$ & 357895 & 514173 & 333974 & 334298 & 413549 & 361861 & 326268 \\
\hline
\end{tabular}

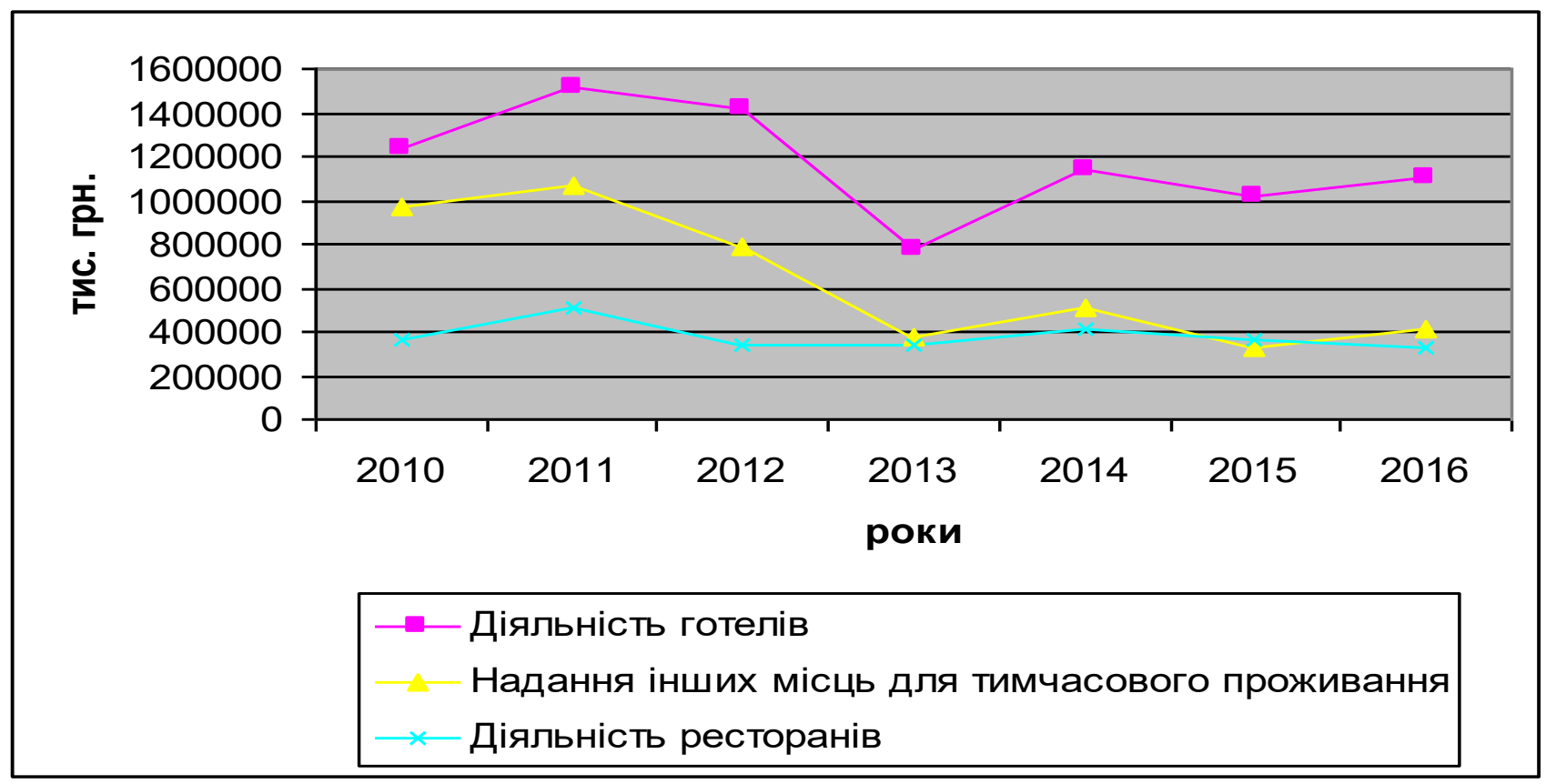

Рис. 2. Динаміка обсягів інвестицій в основний капітал діяльності готелів та ресторанів України за 2010-2016 рр.

Динаміка інвестицій в основний капітал діяльності готелів мала різноспрямований характер: у період 2010-2012 рр. мала позитивний характер; у 2013 р. відбулося значне зменшення; в період 2014-2016 рр. відбувається стабілізація.

Стосовно місць для тимчасового проживання, то динаміка інвестицій мала позитивний тренд до 2011 р., протягом 2012-2013 рр. відбувалося 
зниження, а після 2014 р. відбувається стабілізація.

Динаміка інвестицій у ресторани мала пожвавлення у 2011 р., а у період 2012-2016 рр. значних коливань не відбувалося.

Враховуючи обвал національної валюти у 2013-2014 pp., можна сказати, що у цей період відбулося значне зниження інвестицій у галузь, а наразі триває процес стабілізації.

Аналізуючи проблеми готельної сфери діяльності більш детально, можна зазначити, що рівень забезпечення засобами розміщення та кадрами по регіонах України не $є$ однаковим. Виділяються такі туристичні центри, як Київ, Дніпропетровськ, Донецьк, Львів, Одеса, Харків, де зосереджена значна частина великих готелів і більша частка працівників готельного господарства. Так, у 13-ти містах України сконцентровано більше 30\% фахівців готельної справи. Сформована диференціація кон'юнктури ринку туристичних послуг в різних містах і регіонах України є досить сталою, тому вона має бути об'єктом досліджень, основна мета яких - ефективніше проводити кадрове забезпечення підприємств туристичної галузі в розрізі міст і регіонів для подальшого розвитку туризму [4].

Найбільшу перевагу при наданні туристичних послуг підприємствами готельно-ресторанного бізнесу споживачі (близько 83\% клієнтів) віддають готельному обслуговуванню. Чим вищий середній дохід споживача, тим вищий рівень переваг. Популярним видом послуг, який надається в готелях України, $є$ комплексне обслуговування номерів. Воно становить близько 23\%. Серед послуг, що надаються підприємствами готельно-ресторанного бізнесу, найбільшу питому вагу становить замовлення страв у номер (близько 30\%) [5].

За результатами щорічного дослідження «Глобальний індекс MasterCard найбільш відвідуваних міст» м. Лондон з 2010 року шість разів зберігало перше місце в рейтингу найбільш відвідуваних туристичних напрямків у світі.

Щодо регіонів України, то перше місце серед відвідуваних туристичних напрямків посідає м. Київ. У 2013 році столицю України відвідало близько двох мільйонів іноземних туристів. За результатами «Глобального індексу MasterCard найбільш відвідуваних міст» м. Київ посіло 61-шу позицію, а серед європейських міст - 20-е місце [6].

Вітчизняні фахівці зазначають, що для задоволення потреб гостей місто повинно мати відповідну готельну базу. У 2016 році в Києві функціонувало 167 закладів розміщення різних форм власності та підпорядкування більше ніж на 10 тис. номерів та 18 тис. місць, 3 яких: 122 - готелі, потужністю 9422 номери; 45 - інші засоби тимчасового розміщення (проживання) на 1664 номери [5]. Для задоволення потреб туристів і відвідувачів м. Київ на його ринку послуг гостинності присутні такі міжнародні бренди, як: Radisson, InterContinental, Hyatt International, Hilton, Sheraton Hotels \& Resorts, Marriott International, Accor Group, Holiday Inn, Ramada Encor та інші. Необхідно зазначити, що хоча за абсолютними показниками м. Київ випереджає регіони України [2], але за показником готельних номерів на 1000 приїжджих не 
перевищує аналогічні показники Львова та Одеси. За даним показником м. Київ у рази поступається таким європейським містам як Варшава, Будапешт, Прага, Берлін, Відень [7], які є його прямими конкурентами у туристичній діяльності.

Однією 3 сучасних перспективних тенденцій розвитку готельного господарства України в цілому, та м. Києва зокрема, є орієнтація на екологічність. Станом на січень 2013 року Green Key (престижна міжнародна еко-сертифікація для індустрії дозвілля) надала еко-сертифікати 14 українським підприємствам готельного господарства [8]. Для отримання сертифіката Green Кеу готелям необхідно відповідати ряду екологічних вимог, починаючи від екологічних стандартів і до вимог статуту, наявності плану дій, навчання та зв'язку. Наявність еко-сертифікату Green Key показує відповідальність організації по відношенню до навколишнього середовища та суспільства. У м. Києві його отримали Radisson Blu Hotel, Rus Accord Hotel та Баккара Артготель.

Серед перспективних напрямів готельного бізнесу, як для внутрішнього, так і для зовнішнього ринку, фахівці [9; 10] визначають об'єднання невеликих комфортних готелів на природі. Ця мережа повинна включати сімейні готелі та пансіонати. Головне завдання такої мережі - сформувати ідеологію та новий імідж відпочинку на природі, оптимізувати систему продажів і підготувати іiі гідну презентацію на європейському ринку [5].

Іншим перспективним напрямом розвитку готельного господарства регіонів України може стати створення державних житлово-комунальних підприємств типу «хостел», що будуть надавати «бюджетні» послуги розміщення в рамках регіональних мереж. При цьому надані послуги будуть мати якість, гарантовану державними стандартами. Створення подібних «бюджетних» засобів розміщення спрямовано на посилення внутрішнього та в’їзого туризму так званих «бекпекерів», тобто туристів, що мають при собі лише один рюкзак та зацікавлені лише у «даху». При цьому подібний туризм $\epsilon$ дуже популярним у світі та приносить значний прибуток [11-13].

Забезпечення потреб споживачів шляхом комплексного обслуговування гостей і дотримання такої якості обслуговування безперечно надає конкурентні переваги: поліпшує координацію дій усіх структурних підрозділів підприємств сфери туризму; забезпечує повне задоволення потреб споживачів, заощаджує їхній час і спрощує процедуру одержання послуг; передбачає взаємозамінність працівників і розширення зон обслуговування, що, своєю чергою, дозволяє отримати економічний зиск від усіх видів діяльності.

Ефективна діяльність представників туристичного та готельноресторанного бізнесу має базуватись на означених складових (рис. 3).

Не можна не відзначити, що серед головних сучасних проблем готельного та туристичного бізнесу України $є$ : недостатня кількість кваліфікованих фахівців; низька виконавча та трудова дисципліна персоналу; невідповідність ступеня кваліфікації працівників займаним посадам; низький рівень мотивації працівників. 


\begin{tabular}{|c|}
\hline $\begin{array}{c}\text { Складові ефективної діяльність представників туристичного } \\
\text { та готельно-ресторанного бізнесу }\end{array}$ \\
\hline Визначення сегменту діяльності, що забезпечить можливість задоволення споживачів на ринку \\
конкуруючих продавців \\
\hline Формування чітко сформульованої системи завдань і показників \\
у відповідності до загальних цілей діяльності \\
\hline Збалансоване представництво всіх зацікавлених груп персоналу на самому вищому рівні управління \\
\hline
\end{tabular}

\section{Рис. 3. Складові ефективної діяльність представників туристичного та готельно-ресторанного бізнесу}

Комплекс наявних проблем призводить до низької ініціативності персоналу туристичної галузі при вирішенні завдання найкращого задоволення потреб споживачів.

Висновки 3 даного дослідження та перспективи подальших розвідок. Дослідження стану та динаміки розвитку готельного господарства регіонів України висвітлило неоднорідність розвитку готельного господарства по регіонах України. При цьому необхідно зазначити, що загальна тенденція спрямована у бік зменшення кількості готелів та аналогічних засобів розміщення. Окрім цього, було виявлено зменшення розміру інвестицій з 2010 p. до 2016 р. майже на 58\%. Зменшення кількості готелів та аналогічних засобів розміщення та інвестицій на їх створення та розвиток було пов'язано зі зменшенням кількості туристів. У якості вирішення проблеми було запропоновано зробити акцент на створення мережі спеціалізованих малих сімейних готелів і пансіонатів на природі, що дозволить пожвавити рекреаційний напрям туризму. Також було запропоновано створити спеціалізоване державне житлово-комунальне підприємство типу «хостел», діяльність якого буде спрямовано на надання «бюджетних» місць подорожуючим «бекпекерам» як у межах країни, так і для іноземних туристів, серед яких як раз і популярні такі готелі. Все це дозволить створити збалансований ринок готельного господарства в межах регіонів України, що, своєю чергою, приведе до стимулювання національного та міжнародного в’їзного туризму.

\section{Перелік посилань}

1. ДСТУ 4268:2003 «Послуги туристичні. Заклади розміщування. Загальні вимоги» : сайт. URL : http://dbn.co.ua/load/normativy/dstu/5-1-0-941.

2. «Регіони України» 2016 рік. Частина II. : сайт. URL http://www.ukrstat.gov.ua.

3. Мальська М. П., Рутинський М. Й., Паньків Н. М. Туризм у міжнародному i національному вимірах. Історія і сучасність : монографія. Львів: Вид. центр ЛНУ, 2008. 360 с.

4. Бунтова Н. В. Кадрове забезпечення галузі туризму з урахуванням міжнародного досвіду : сайт. URL http://dspace.nbuv.gov.ua/handle/123456789/11786.

5. Мархонос С. М., Турло Н. П. Туристична сфера як фактор підвищення інвестиційної привабливості регіону. Економіка. Управління. Інновації. 2012. 
№ 1 : сайт. URL : http://nbuv.gov.ua/UJRN/eui_2012_1_30.

6. Постірух О. Компанія Mastercard назвала найбільш відвідувані міста світу у 2017 : сайт. URL : https://newsroom.mastercard.com/eu/uk/newsbriefs/mastercard-nazvala-naibilsh-vidviduvani-mista.

7. The World Tourism Organization (UNWTO) : сайт. URL : www.unwto.org.

8. The Green Key organization : сайт. URL : http://www.greenkey.global.

9. Ткаченко Т. І. Сталий розвиток туризму: теорія, методологія, реалії бізнесу. 2-ге вид., випр. та доповн. К. : Київ. нац. торг.-екон. ун-т, 2009. 463 с.

10. Стратегічний розвиток туристичного бізнесу : монографія / Ткаченко Т. І., Мельниченко С. В., Бойко М. Г. та ін. ; за заг. ред. А. А. Мазаракі. К. : Київ. нац. торг.-екон. ун-т, 2010. 596 с.

11. Mohn T. Travel Boom: Young Tourists Spent \$217 Billion Last Year, More Growth Than Any Other Group. URL : https://www.forbes.com/sites/tanyamohn/2013/10/07/the-new-young-travelerboom/\#7ee5d7cc4ff1.

12. Рябєв А. А. Дослідження ринку споживчого попиту на прикладі готельних послуг. Проблеми і перспективи розвитку підприємництва. 2015. № 3(1), C. 31-35.

13. Рябев А. А. Готельні та хостельні мережі: дослідження споживчого попиту. Проблеми і перспективи розвитку підприємниџтва. 2016. № 2(13), том 1. C. 94-101.

\section{References}

1. DSTU 4268: 2003 "Tourist services. Accommodation facilities. General requirements"[DSTU 4268:2003 „Poslugi turistichni. Zakladi rozmischuvannya. Zagalni vimogi"], available at: http://dbn.co.ua/load/normativy/dstu/5-1-0-941. (last accessed 13.02.2020).

2. Regions of Ukraine ”2016. Part II [,Regioni Ukrayini” 2016 rik. Chastina II], available at: http://www.ukrstat.gov.ua. (last accessed 13.02.2020).

3. Malska, M. P., Rutinskiy, M. Y. and Pankiv, N. M. (2008), Tourism internationally and nationally. History and modernity: monograph [Turizm $u$ mizhnarodnomu i natsionalnomu vimirah. Istoriya $i$ suchasnist : monografIya], Lviv: Ed. center of LNU, $360 \mathrm{p}$.

4. Buntova, N. V. (2012), Staffing of the tourism industry with international experience [Kadrove zabezpechennya galuzi turizmu $\mathrm{z}$ urahuvannyam mizhnarodnogo dosvidu], available at: http://dspace.nbuv.gov.ua/handle/123456789/11786 (last accessed 13.02.2020).

5. Marhonos, S. M. and Turlo, N. P. (2012), "Tourism as a factor in increasing the investment attractiveness of the region"nu [Turistichna sfera yak faktor pidvischennya investitsiynoyi privablivosti regio], Economy. Management. Innovations, No.1, available at: http://nbuv.gov.ua/UJRN/eui_2012_1_30 (last accessed 13.02.2020).

6. Postirukh, O. (2017), Mastercard named the world's most visited cities in 2017 [Kompaniia Mastercard nazvala naibilsh vidviduvani mista svitu u 2017], 
available at: https://newsroom.mastercard.com/eu/uk/news-briefs/mastercardnazvala-naibilsh-vidviduvani-mista.

7. The World Tourism Organization (UNWTO), available at: www.unwto.org (last accessed 13.02.2020)

8. The Green Key organization, available at: http://www.greenkey.global (last accessed 13.02.2020).

9. Tkachenko, T. I. (2009), Sustainable development of tourism: theory, methodology, business realities [Staliy rozvitok turizmu: teoriya, metodologiya, realiyi biznesu], К.: Київ. nat. trade and economy un-t, 463 p.

10. Tkachenko, T. I., Melnichenko, S. V., Boyko, M. G. and oth. (2010), Strategic development of tourism business [Strategichniy rozvitok turistichnogo biznesu], in Mazaraki A. А. (ed.), К.: Київ. nat. trade and economy un-t, 596 p.

11. Mohn, T. (2013), Travel Boom: Young Tourists Spent \$217 Billion Last Year, More Growth Than Any Other Group., available at: https://www.forbes.com/sites/tanyamohn/2013/10/07/the-new-young-travelerboom/\#7ee5d7cc4ff1 (last accessed 13.02.2020).

12. Ryabev, A. A. (2015), „The Consumer market demand research on example of hotel services" ["Doslidzhennya rinku spozhivchogo popitu na prikladiI gotelnih poslug"], Problems and Perspectives of Entrepreneurship Development, No. 3 (1), P. 31-35.

13. Ryabev, A. A. (2016), "Hotel and hostel networks: consumer demand research"["Gotelni ta hostelni merezhi: doslidzhennya spozhivchogo popitu"], Problems and Perspectives of Entrepreneurship Development, No. 2 (13), part 1, P. 94-101.

\section{PЕФЕРАТИ РЕФЕРАТЫ ABSTRACTS \\ УДК 338.48; JEL Classification: L 830}

РЯбєВ А.А. АНАЛІЗ СТАНУ ГОТЕЛЬНОГО ГОСПОДАРСТВА

\section{РЕГІОНІВ УКРАЇНИ}

Мета. Виходячи 3 визначення невирішеності проблемного питання, необхідно визначити стан і динаміку розвитку готельного господарства регіонів України, як складової туристичної галузі, що дозволить виділити напрями перспективного розвитку готельного господарства в регіонах України. Результати дослідження. У статті здійснено дослідження стану та динаміки розвитку готельного господарства регіонів України за період 2010-2016 рр., на основі якого виявлено неоднорідність розвитку готельного господарства по регіонах України та визначено, що загальна тенденція спрямована у бік зменшення кількості готелів та аналогічних засобів розміщення. Окрім цього, було виявлено зменшення розміру інвестицій з 2010 року по 2016 рік майже на $58 \%$. Зменшення кількості готелів та аналогічних засобів розміщення та інвестицій на їх створення та розвиток було пов'язано зі зменшенням кількості туристів, що, відповідно, негативно відбилося на загальному стані туристичної індустрії України. Практична значущість. У якості вирішення визначеної проблеми було запропоновано зробити акцент на створенні мережі 
спеціалізованих малих сімейних готелів і пансіонатів на природі, що дозволить пожвавити рекреаційний напрям туризму. Також було запропоновано створити спеціалізоване державне житлово-комунальне підприємство типу «хостел», діяльність якого повинна бути спрямована на надання «бюджетних» місць подорожуючим «бекпекерам» як у межах країни, так і для іноземних туристів, серед яких як раз і популярні такі готелі. Запропоновані заходи дозволять створити збалансований ринок готельного господарства та готельних послуг в межах регіонів України (не лише середньої та вищої цінової категорій, але й «бюджетної»), що, своєю чергою, приведе до стимулювання національного та міжнародного в'їзного туризму.

Ключові слова: готельне господарство; розвиток туризму; регіони України; житлово-комунальне підприємство «хостел».

\section{УДК 338.48; JEL Classification: L 830}

\section{Рябев А.А. АНАЛИЗ СОСТОЯНИЯ ГОСТИНИЧНОГО ХОЗЯЙСТВА РЕГИОНОВ УКРАИНЫ}

Цель. Исходя из выявления нерешенности проблемного вопроса, необходимо определить состояние и динамику развития гостиничного хозяйства регионов Украины, как составляющей туристической отрасли, что позволит выделить направления перспективного развития гостиничного хозяйства в регионах Украины. Результаты. В статье проведено исследование состояния и динамики развития гостиничного хозяйства регионов Украины за период 2010-2016 гг., на основе которого обнаружено неоднородность развития гостиничного хозяйства по регионам Украины и определено, что общая тенденция направлена в сторону уменьшения количества гостиниц и аналогичных средств размещения. Так же было выявлено уменьшение размера инвестиций с 2010 года по 2016 год почти на 58\%. Уменьшение количества гостиниц и аналогичных средств размещения и инвестиций на их создание и развитие было связано с уменьшением количества туристов, что, соответственно, негативно отразилось на общем состоянии туристической индустрии Украины. Практическая значимость. В качестве решения определенной проблемы было предложено сделать акцент на создании сети специализированных малых семейных гостиниц и пансионатов на природе, что позволит оживить рекреационное направление туризма. Также было предложено создать специализированное государственное жилищнокоммунальное предприятие типа «хостел», деятельность которого должна быть направлена на предоставление «бюджетных» мест путешествующим «бекпекерам» как внутри страны, так и для иностранных туристов, среди которых как раз и популярны такие отели. Предложенные меры позволят создать сбалансированный рынок гостиничного хозяйства и гостиничных услуг в пределах регионов Украины (не только средней и высшей ценовой категорий, но и «бюджетной»), что, в свою очередь, приведет к стимулированию национального и международного въездного туризма.

Ключевые слова: гостиничное хозяйство; развитие туризма; регионы 
Украины; жилищно-коммунальное предприятие «хостел».

\section{UDC 338.48; JEL Classification: L 830}

\section{Ryabev A.A. ANALYSIS OF STATE OF THE HOTEL INDUSTRY IN THE REGIONS OF UKRAINE}

Purpose. On basing on the definition of unresolved problematic issues, it is necessary to determine the state and dynamics of the development of the hotel industry in the regions of Ukraine, as an integral part of the tourism industry, that will give opportunity to identify areas for the prospective development of the hotel industry in the Ukrainian regions. Findings. The article studies the state and dynamics of the development of hotel industry in the regions of Ukraine for the period 2010-2016. Based on this, heterogeneity in the development of hotel industry in the regions of Ukraine was found and it was determined that the general trend is directed towards reducing the number of hotels and similar accommodation facilities. In addition, a decrease in the size of investments from 2010 to 2016 was found to be almost 58\%. The decrease in the number of hotels and similar means of accommodation and investment in their creation and development was associated with a decrease in the number of tourists, respectively, negatively affected the general state of the tourism industry in Ukraine. Practical value. As a solution to a particular problem, it was proposed to focus on creating a network of specialized small family hotels and pensions in nature, which will revive the recreational direction of tourism. It was also proposed to create a specialized state-owned housing and communal enterprise such as a "hostel", the activity of which should be aimed at providing "budget-friendly" places for "backpackers", both domestically and for foreign tourists, among which such hotels are in demand. The proposed measures will create a balanced market for hotel industry and hotel services within the regions of Ukraine (not only the middle and highest price categories, but also "budget"), which in turn will lead to the stimulation of national and international inbound tourism.

Key words: hotel industry; tourism development; regions of Ukraine; housing and communal enterprise "hostel".

\section{Відомості про автора / Сведения об авторе / About the Author}

Рябєв Антон Анатолійович - кандидат економічних наук, доцент, Харківський національний університет міського господарства ім. О.М. Бекетова, доцент кафедри туризму і готельного господарства, м. Харків, України; e-mail: kharkov-kruiz@mail.ru; ORCID: 0000-0003-2220-3282. Моб. 067-579-35-47.

Рябев Антон Анатольевич - кандидат экономических наук, доцент, Харьковский национальный университет городского хозяйства им. А.Н. Бекетова, доцент кафедры туризма и гостиничного хозяйства, г. Харьков, Украина.

Ryabev Anton A. - $\mathrm{PhD}$ in Economics, Associate Professor, O.M. Beketov National University of Urban Economy in Kharkiv, Associate Professor of the Department of Tourism and Hospitality. 